\title{
RISK AGENTS RELATED TO WORK AND AMYOTROPHIC LATERAL SCLEROSIS: AN OCCUPATIONAL MEDICINE FOCUS
}

\section{ELPIDIO MARIA GARZILLO, NADIA MIRAGLIA, PAOLA PEDATA, DANIELA FEOLA, and MONICA LAMBERTI}

Second University of Naples, Naples, Italy

Department of Experimental Medicine, Section of Hygiene, Occupational Medicine and Forensic Medicine,

Occupational Medicine Area

\begin{abstract}
Amyotrophic lateral sclerosis (ALS) is a neurodegenerative disease characterized by progressive muscular paralysis reflecting degeneration of motor neurons. In recent years, in addition to several studies about genetic mechanisms leading to motor neurons damage, various epigenetic theories have been developed, involving the study of the patients' work and lifestyle. The work aims at focusing the role of occupational exposure related to ALS by literature data analysis. Articles, selected on the basis of keywords, year of publication and topics, are related to occupational exposure, suggesting an impact on ALS onset. The literature review shows that there are still a lot of biases in the studies design, which actually do not allow to draw unequivocal conclusions.
\end{abstract}

Key words:

Occupational exposure, Amyotrophic lateral sclerosis, Occupational medicine, Neurodegenerative processes,

Heavy metals, Working adults

\section{INTRODUCTION}

Amyotrophic lateral sclerosis (ALS) is a rare and severe human motor system disease due to motor neurons degeneration. The ALS definition's criteria were established by El Escorial in 1998 and recently revised by the Awaji Commission proposing a modification of the electrodiagnostic criteria for ALS [1]. A pathophysiological hypothesis elaborated to explain neurodegeneration that leads to the ALS is not yet fully defined: recent research has focused on genetic and epigenetic alterations associated with environmental and occupational factors. In a small percentage of patients (6-10\%) ALS is a familial form, transmitted as an autosomal recessive or dominant form [2]. In $25 \%$ of these patients there is a detectable point mutation of the gene coding for superoxide dismutase (SOD) 1, located on chromosome 21 [3,4].

Growing scientific evidence has supported the new hypothesis of ALS as a multisystem disease that affects executive and behavioral functions, language and other various cognitive domains, functionally associated with temporal and frontal lobes [5].

Amyotrophic lateral sclerosis has a poor prognosis, with the incidence rate of $0.4-2.5$ cases per 100000 people per year, and a mortality rate of $0.8-2.1$ cases per

Received: June 27, 2014. Accepted: June 25, 2015.

Corresponding author: E.M. Garzillo, Second University of Naples, Department of Experimental Medicine, Section of Hygiene, Occupational Medicine and Forensic Medicine, Occupational Medicine Area, Via L. de Crecchio 7, 80138 Naples, Italy (e-mail: elpidio.m.garzillo@gmail.com). 
100000 people per year. It is a typical adulthood disease, with the apparent increased incidence among those in a more advanced age [6].

In the epidemiological works, analyses show a considerable range of variation in the incidence rate, which can be largely explained by different methods used for identification of cases and the size of the used sample [7]. The prevalence of ALS is approximately 6-8 cases per 100000 inhabitants, or about 4500 people living with ALS in Italy. The average onset age is about 65 years, with a peak incidence between 64 and 75 years in both sexes. Relatively frequent cases with the early age of onset ( $<40$ years) have a more benign clinical course than the classic onset in adulthood [8]. The increase of ALS diagnoses can be probably attributed both to an improvement in the accuracy of death certificates and understanding of the pathophysiological mechanisms related to risk factors, including, occupational and environmental exposures (such as electromagnetic fields exposure, polychlorinated biphenyls, metals and pesticides, smoking, head trauma and professions that require heavy physical exertion) $[8,9]$.

In particular, in the recent years the study of the role of occupational factors in the context of the onset of ALS has acquired increasing interest. Even considering "unconventional" risk factors, such as, e.g., ultrafine particles associated with the genesis of accumulation and likely to damage neuronal cells $[10,11]$ or some metals that could be involved in the mechanisms of neuronal injury (such as aluminium) [12].

\section{MATERIAL AND METHODS}

The literature review has been divided into 2 phases. The 1st phase was carried out through collection of articles related to the topic under the study, in terms of the pathophysiology of ALS and epidemiological data, focusing on environmental/occupational exposure to neurodegenerative risk factors, with particular tropism for motor neurons.
Subsequently, the authors made a selection of the collected articles by outlining selection/exclusion criteria. The used selection criteria were: range of years 19912014; databases such as Pubmed/Medline and the Cochrane Database of Systematic Reviews. In order to identify efficient search strategies regarding occupational health research, the search for relevant articles was performed using the following keywords "ALS/occupational exposure," "ALS/occupational disease," "environmental/ ALS," "heavy metals/ALS" [13].

The following exclusion criteria were adopted: articles relating exclusively to environmental exposure, without any occupational exposure assessment; articles concerning occupational therapy. An important exclusion criterion during the manual selection of articles was also to select papers concerning very specific themes in relation to the hypothetical occupational exposure. Another scientific commitment made by the authors was to include the selected articles in specific areas, by article types, in order to configure the current areas of interest. The results are summarized in Table 1.

The work was based on a revision of the selected articles, highlighting the relationship between the risk agents, employment sectors and the onset of ALS.

\section{RESULTS}

Considering the inclusion criteria and research query, the total number of papers to be included in the study was about 200. However, this number was reduced to 80 according to the exclusion criteria. The authors analyzed the selected articles based on the above mentioned criteria (the detailed data and statements in this paragraph are shown in Table 2). The strong presence of articles that relate to the agricultural sector should be noted - those were mostly epidemiological studies. Other research works have focused on pesticides, in terms of toxicological effect. In the case of other occupational sectors (e.g., industrial sector) there were mainly epidemiological papers or meta-analyses. 
Table 1. Main study designs in the literature about the relationship between amyotrophic lateral sclerosis (ALS) and occupational exposure

\begin{tabular}{lcc}
\hline \multicolumn{1}{c}{ Article type } & Years of publication & Reference \\
\hline Original articles about familial ALS & $1993-1999$ & 2,4 \\
Original articles about pathogenetic mechanism & $2003-2013$ & $3,5,76,80-82,84,87,88$ \\
Epidemiological studies & $1991-2014$ & $6-8,13-17,23,24,39,40,42,43,45,46,48$, \\
& & $50,51,54-62,66-68$ \\
Epidemiological studies related to occupational exposure & $1991-2014$ & $9,18-22,25-28,31,32,36-38,41,47,65,74$ \\
Case reports & $1992-2012$ & $33-35,75,78,79,85,86$ \\
Critical research aspects and new methodological proposals & $2009-2014$ & $69,70-72,77,80,83,89-91$ \\
\hline
\end{tabular}

Table 2. Key scientific articles about the relationship between amyotrophic lateral sclerosis (ALS) and occupational exposure

\begin{tabular}{lcc}
\hline \multicolumn{1}{c}{ ALS and occupational exposure in articles } & Years of publication & Reference \\
\hline $\begin{array}{l}\text { Epidemiological studies on the correlation between } \\
\text { environmental and occupational exposures }\end{array}$ & $1991-2013$ & $7,9,13-26,28,36$ \\
and the onset of ALS & & \\
Pesticides exposure & $2001-2012$ & $41-47$ \\
Research carried out in industrial workers & $1997-2014$ & $48-51$ \\
Studies in the military work sector & $2002-2009$ & $40-41,52-60$ \\
Exposure to intense sports activities, trauma, hypoxia & $1997-2014$ & $61-69$ \\
Exposure to electromagnetic fields & $2002-2012$ &
\end{tabular}

Some evidence suggests a possible association between a neuro-disease and specific work activities. Workers involved in the production of power plants, athletes, military workers, those exposed to electromagnetic fields and those involved in the production of nickel cadmium batteries appear to be at an increased risk of ALS onset.

It has also been observed that attention of the international scientific community in the field of occupational exposure to metals is also increasing. Recently there have been many studies concerning heavy metals and other chemicals that may be involved in the onset of the disease. Lead is one of the metals the neurotoxic potential of which is best known, as it has been widely studied for years. These studies have allowed to correlate exposure to this metal to ALS cases and also to hypothesize the pathophysiological mechanisms that underlie motor neuron degeneration. Other works related to metals have also been included, nevertheless we have to clarify that those were only few occupational medicine studies, most of them aiming at construction of experimental models useful in understanding the mechanisms of neuronal injury.

\section{DISCUSSION}

From the late 1980s to the present, knowledge about pathophysiological mechanisms of neurodegenerative diseases have led to the development of epigenetic hypothesis about the onset and progression of motor neuron degeneration. Since then, international scientific literature has developed, especially studies regarding epidemiological 
and environmental/occupational exposure in order to investigate the risk factors associated with ALS [14-21]. Sutedja et al. [22] have criticized all the work produced until 2006, outlining heterogeneity and different methodological bias in collecting information and outlining the need for well-designed studies carried out through careful standardized assessment of the occupations investigated so as to provide a more definitive answer concerning exogenous risk factors of ALS. In addition, the authors have outlined, among the first, some jobs or work areas in the case of which the studies have shown a strong correlation with ALS cases, i.e., athletes, hairdressers, electricians and military personnel.

The main papers published during the past 15 years have analyzed, by the use of epidemiological studies, possible environmental and occupational exposures, and employment sectors related to these exposures in order to search for plausible risk factors correlated with the ALS onset [23-25]. Retrospective epidemiological studies have been performed over years, starting in the early 1990s [26,27]. Cases of pathology within specific working sectors have been described, such as those involved in the clothing industry, industry in which exposure to formaldehyde occurs [28], and in the case of exposure to diesel exhaust, described by Pamphlett et al. [29].

Agricultural working sector has been widely studied because of occurring in it exposure to several risk factors, such as, e.g., pesticides [30].

Although ALS is considered a systemic disease [31], pesticides, in general, have long been suspected as important risk factors in the pathogenesis of ALS due to their toxicokinetic and toxicodynamic characteristics likely to induce damage to the peripheral motor neurons. Epidemiological work about exposure to this risk factor, has been conducted recently on the Italian territory [32,33].

Risk factors supposedly involved in the genesis of neurodegeneration might include specific chemicals, including fertilizers, herbicides, fungicides, insecticides, etc. [34,35].
In the literature there are some articles based on the study of exposure to particular substances the action of which could trigger mechanisms of neuronal damage, such as: 2,4-dichlorophenoxyacetic acid [36], pyrethroid insecticides [37], or other metabolites of organophosphorus compounds [38]. Currently, it has been suggested that not only the use of fertilizers and pesticides, but also the intense physical activity characteristics of the agricultural work - with a strong cardio-metabolic tasks and frequent anaerobic periods - might be considered as a risk factor in ALS [14].

A recent meta-analysis (2012) evaluating correlation studies between exposure to chemicals in agriculture and the ALS development, has supported the close relationship: the weight of evidence showing a strong connection to pesticides exposure [35]. In summary, scientific literature relating occupational exposure to ALS is characterized by epidemiological studies aimed at the evaluation of known exposures. For example, all of the studies conducted by Malek et al. are constructed with this regard, with a specific focus on the pesticides action, which appears to play a crucial role in the development and progression of this neurodegenerative disease $[34,39]$.

Exposure to xenobiotics from vehicular traffic or spinal microtrauma related to the whole-body vibrations while driving may represent factors that contribute to the anticipated onset [40]. Some studies have tested the hypothesis that ALS develops when physical activity is very intense and particular exposure to various risk factors are combined with a genetic makeup that prevents a normal response to hypoxia. It has been shown, e.g., that a profession such as fireman, that precisely combines an intense physical activity with episodes of hypoxia, results in a double risk of developing ALS compared to the rest of the population [41].

In the industrial sector, heterogeneity of risk factors to which workers may potentially be exposed does not lead to a clear conclusion about the identification of a particular 
risk factor or a specific work activity correlated with the disease. According to epidemiological studies [42], risk factors very common in the industry are mixed exposures to a number of substances, such as metals (lead, arsenic and thallium) or acrylamide, hexane, trichlorethylene, etc. Evaluating data literature, it can be assumed that a variety of physical and chemical xenobiotics, as well as hard work in shifts, may contribute to the development of motor neuron degeneration [14,41]. Several studies have shown a slight disease prevalence and an increased ALS risk in some specific industrial sectors such as e.g., electrical industry in professions such as: electricians, installers and repairers of electrical energy, power plant operators, electrical and electronic equipment repairers, machinists, telephone installers and repairers, and workers involved in the maintenance of electrical equipment [43,44]. Among these jobs, specific evidence has been shown in the case of employees of plants producing electrical capacitors: epidemiological studies have shown an increase in mortality rates for cancer and neurodegenerative diseases, including ALS, probably correlated with polychlorinated biphenyls exposure $[45,46]$.

Other data derived from the study of subjects exposed to electric shock at work [47], but those data have been recently refuted by a systematic review [48], in which a reanalysis of all the evidence has not supported a causal relationship between ALS and electrical shocks exposure adequately.

Other specific activities or work sectors have been examined over the years. Epidemiological studies have evaluated working sectors where there is a multiplicity of xenobiotics exposure or traumatic events, often unrecognized, which can be correlated with the development of neuronal damage associated with ALS. Among them, there is a military activity, but often assessment of complex exposures in military services is difficult [49-52].

Another peculiar activity that has been examined is professional sport. This review showed a focus of interest on the possible correlation between pathology onset in professional football players. From those studies, a new hypothesis emerged, proposing an explanation of the excess mortality for ALS among football players, in the case of who the following risk factors occur: trauma or microtrauma specific vigorous physical activity; the use of toxic or abuse of illegal drugs (most often anti-inflammatory drugs) and dietary supplements and, finally, pesticides exposure used on the fields of play [53-59]. Other papers have suggested that hypoxia related to aerobic exercise and anaerobic high-grade (such as that seen in professional athletes) could have a link to ALS development in susceptible individuals [41,60]. Recent work also shows an increased ALS risk in relation to higher levels of amateur physical activity. In this study, the lack of association between occupational physical activity and the absence of a dose-response relationship supports the hypothesis that increasing ALS susceptibility is not increased exclusively by physical activity but rather also by genetic profile or life habits [61].

Exposure to electromagnetic fields has been studied in epidemiological [62-66], observational [67] and laboratory works [68]. A recent meta-analysis suggests a slightly but significantly increased risk of ALS among workers exposed to an extremely low frequency electromagnetic field (ELF-EMF), but does not deny the possibility of bias in the data analysis [69]. However, in the case of electromagnetic fields, there are many problems: at present, no apparent correlation between the exposure assessment and the observed associations is possible. In order to better assess exogenous risk factors of ALS, a job exposure matrix (JEM) may have to be used, with a detailed exposure index to electric fields and magnetic fields [70].

Metals have been studied for a long time in order to understand pathogenic mechanisms underlying development of neurodegenerative disease better, and to date there are prospects of study for this topic [71]. Although numerous conclusions have emerged from epidemiological evidence, 
there is still no consensus about the unique involvement of metals in the etiology of ALS .

New research projects will be needed for various purposes, i.e., a better setting of therapeutic protocols, prevention programs promotion and improvement of patients' quality of life [72]. Some studies published in 2014 are investigating the role of environmental/occupational exposure in progression of neurodegenerative diseases in the context of prenatal and postnatal life, explaining how molecular mechanisms that mediate epigenetic changes can lead to neurological disorders [73].

Association between ALS and occupational exposure to lead $(\mathrm{Pb})$ has been studied for a long time: an important work has been carried out by Gresham et al. [74], and then it has been later followed by other epidemiological works [75]. In addition, there are case reports that evaluate the onset of ALS associated with a specific work activity characterized by $\mathrm{Pb}$ exposure [76].

Scientific evidence has shown metals presence in the cerebrospinal fluid, suggesting fascinating perspectives for future research. In particular, Hozumi et al. have described different patterns of metals concentrations specific for different types of neurodegenerative diseases [77].

Some metals investigated as implicated in ALS are correlated to the mercury $(\mathrm{Hg})$ and cadmium. Mercury may be implicated as a risk factor for development of the pathology [78]. Clinical ALS symptoms in patients accidentally exposed to $\mathrm{Hg}$ [79] have been observed in a work published by Schwarz et al. [79]. Some hypotheses have suggested that chronic respiratory exposure, in a low dose, to certain metals, such as $\mathrm{Hg}$, might contribute to neurodegenerative diseases genesis, including motor neuron disease [80]. Several laboratory [81], epidemiological studies [82], and case reports [83] have confirmed the possible implication of $\mathrm{Hg}$. Observing the conflicting evidence in the literature regarding the role of $\mathrm{Hg}$ in the etiology of ALS, is hoped to bring about a greater interest in this topic [84].
As for cadmium, apart from recent evidence of a high metal concentration in the cerebrospinal fluid of ALS patients [85], there are some works focusing on occupational exposures in certain employment sectors, such as production of nickel-cadmium batteries [86,87]. Some evidence in experimental models concerning neurotoxicity of other metals such as zinc and copper $[88,89]$ is also present in scientific literature, but there is no strong evidence concerning relationship with ALS. Little evidence about occupational exposure to aluminum and the onset of neurological disorders compatible with degenerative motor neuron disease is present in scientific literature: SińczukWalczak [90] has examined aluminium effects on the functions of the nervous system in people occupationally exposed to dust and fumes containing this metal. The author has mostly found neuro-behavioral and bioelectric cerebral disorders, and less frequently neurological symptoms correlated with a motor neuron disease.

In Table 3 the authors summarized the most important evidence in the literature, selecting only the most recent observations (including range period 2011-2014) from the exposed workers. In conclusion, the data in Table 3 are intended to outline the state of ALS and occupational medicine, outlining the areas of research and observations that may be starting points for the development of future issues.

\section{CONCLUSIONS}

Etiology of ALS, as well as the onset mechanisms are not yet fully understood. However, recent evidence increasingly shows a strong correlation between ALS and occupational and environmental hazards, including exposure to various xenobiotics, such as heavy metals and solvents.

This revision focused on occupational exposure studies, in order to outline the most current research themes and the most recent evidence regarding ALS onset and working activities (Table 3). The recent discovery that genetic 
Table 3. Recent main findings about the relationship between amyotrophic lateral sclerosis (ALS) and occupational exposure

\begin{tabular}{|c|c|c|}
\hline Reference & Study design & Main finding \\
\hline Bettini et al. (2011) [25] & register based cohort & $\begin{array}{l}\text { epidemiology of ALS in Buenos Aires: } 40 \% \text { were employed in elementary } \\
\text { occupations, } 19 \text { technicians and } 8 \text { handicraftsmen }\end{array}$ \\
\hline Pinkerton et al. (2012) [28] & register based cohort & $\begin{array}{l}\text { the results of the study do not suggest that ALS is associated with } \\
\text { formaldehyde exposure }\end{array}$ \\
\hline Pamphlett et al. (2013) [29] & case-controls & $\begin{array}{l}\text { the exposure to diesel exhaust may underlie some of the occupations } \\
\text { involved in ALS development }\end{array}$ \\
\hline Das et al. (2012) [14] & case-controls & $\begin{array}{l}\text { insecticides and pesticides exposures, electrical injury as associated factors } \\
\text { in ALS development }\end{array}$ \\
\hline Hargreaves et al. (2012) [31] & review & $\begin{array}{l}\text { organo-phosphorus compounds exposure could lead to several neural } \\
\text { damage involved in ALS onset }\end{array}$ \\
\hline Kanavouras et al. (2011) [36] & case-report & $\begin{array}{l}\text { an evidence based case of combined exposure to organo-chlorine (DDTs), } \\
\text { organophosphate pesticides (OPs) and organic solvents, linked } \\
\text { to ALS onset }\end{array}$ \\
\hline Malek et al. (2014) [37] & case-controls & $\begin{array}{l}\text { occupational exposure to metals and pesticides was related to } \\
\text { increased ALS risk; no associations were found for occupational exposure } \\
\text { to organic or aromatic solvents }\end{array}$ \\
\hline Lehman et al. (2012) [55] & register based cohort & $\begin{array}{l}\text { an increased risk of neurodegenerative disease (and ALS) among football } \\
\text { players }\end{array}$ \\
\hline Huisman et al. (2013) [61] & case-controls & $\begin{array}{l}\text { not increased physical activity per se but rather a genetic profile or lifestyle } \\
\text { promoting physical fitness increases ALS susceptibility }\end{array}$ \\
\hline Kamel et al. (2012) [39] & meta-analysis & $\begin{array}{l}\text { amyotrophic lateral sclerosis risk is associated with use of pesticides } \\
\text { as a group, organo-chlorine insecticides use in particular }\end{array}$ \\
\hline Vinceti et al. (2012) [23] & review & $\begin{array}{l}\text { evidence for an association between ALS and heavy metals, selenium and } \\
\text { pesticides exposure; the relation with mercury, cadmium, and lead appears } \\
\text { weaker }\end{array}$ \\
\hline Parlett et al. (2011) [65] & register based cohort & $\begin{array}{l}\text { no evidence for an association between magnetic field exposure } \\
\text { and ALS mortality }\end{array}$ \\
\hline Bastos et al. (2011) [72] & review & $\begin{array}{l}\text { some evidence about ALS onset and some occupational exposure, but } \\
\text { there's still no consensus on specific etiology }\end{array}$ \\
\hline Zhou et al. (2012) [69] & meta-analysis & $\begin{array}{l}\text { slight but significant ALS risk increase among job titles related } \\
\text { to ELF-EMF exposure }\end{array}$ \\
\hline Pupillo et al. (2014) [59] & register based cohort & $\begin{array}{l}\text { physical activity (measured in METs) cannot be not a risk factor for ALS } \\
\text { and may eventually be a protective agent against the disease }\end{array}$ \\
\hline Callaghan et al. (2011) [78] & review & $\begin{array}{l}\text { some evidence leads to the hypothesis that an interaction between heavy } \\
\text { metal exposure and an individual's genetic makeup is required to produce } \\
\text { epigenetic changes that ultimately lead to ALS }\end{array}$ \\
\hline
\end{tabular}

DDT - dichlorodiphenyltrichloroethane; ELF-EMF - extremely low-frequency electromagnetic field; MET - metabolic equivalent.

mutations, such as those relating to the SOD-1 in patients suffering from ALS, could hypothetically be due to epigenetic mechanisms and makes it particularly desirable to orient future research towards the study of environmental risk factors and working conditions capable of producing such mutations. Epigenetic mechanisms, playing a crucial 
role in the gene expression control, may be involved in the complexity of the disease in its phenotypes and progression [91-93].

The review shows that although a number of scientific data in the evaluation of non-genetic causes of ALS onset has increased, yet well-documented works concerning the study of work activities, and the inferences that would confirm the possible connection between occupational exposure to risk factors and the onset of ALS, are still lacking.

New research projects would be needed for various purposes, i.e., for better setting of therapeutic protocols for the promotion of prevention programs and for improvement of the quality of life of such patients [71].

\section{REFERENCES}

1. Boekestein WA, Kleine BU, Hageman G, Schelhaas HJ, Zwarts MJ. Sensitivity and specificity of the "Awaji" electrodiagnostic criteria for amyotrophic lateral sclerosis: Retrospective comparison of the Awaji and revised El Escorial criteria for ALS. Amyotroph Lateral Scler. 2010 Dec;11(6):497-501, http://dx.doi.org/10.3109/17482961003777462.

2. Rabin BA, Griffin JW, Crain BJ, Scavina M, Chance PF, Cornblath DR. Autosomal dominant juvenile amyotrophic lateral sclerosis. Brain. 1999;122:1539-50, http://dx.doi. org/10.1093/brain/122.8.1539.

3. Appel SH, Zhao W, Beers DR, Henkel JS. The microglialmotoneuron dialogue in ALS. Acta Myol. 2011 Jun;30(1):4-8.

4. Rosen DR, Siddique T, Patterson D, Figlewicz DA, Sapp P, Hentati A, et al. Mutations in $\mathrm{Cu} / \mathrm{Zn}$ superoxide dismutase gene are associated with familial amyotrophic lateral sclerosis. Nature. 1993;362:59-62, http://dx.doi.org/10.1038/362059a0.

5. Abrahams S, Goldstein LH, Suckling J, Ng V, Simmons A, Chitnis $\mathrm{X}$, et al. Frontotemporal white matter changes in amyotrophic lateral sclerosis. J Neurol. 2005;252(3):321-31, http://dx.doi.org/10.1007/s00415-005-0646-x.

6. Altavista P, Belli S, Binazzi A, Comba P, Mastrantonio M, Uccelli R, et al. Increase in mortality for motor neuron disease in Italy, 1980-1999. Epidemiol Prev. 2006;30(2):108-13.
7. Worms PM. The epidemiology of motor neuron diseases: A review of recent studies. J Neurol Sci. 2001;191(1-2):3-9, http://dx.doi.org/10.1016/S0022-510X(01)00630-X.

8. Qureshi MM, Hayden D, Urbinelli L, Ferrante K, Newhall K, Myers D, et al. Analysis of factors that modify susceptibility and rate of progression in amyotrophic lateral sclerosis (ALS). Amyotroph Lateral Scler. 2006;7:173-82, http://dx.doi.org/10.1080/14660820600640596.

9. Sutedja NA, Veldink JH, Fischer K, Kromhout H, Heederik D, Huisman MH, et al. Exposure to chemicals and metals and risk of amyotrophic lateral sclerosis: A systematic review. Amyotroph Lateral Scler. 2008;8:1-20, http://dx.doi. org/10.3109/17482960802455416.

10. Pedata P, Garzillo EM, Sannolo N. [Ultrafine particles and effects on the body: Review of the literature]. G Ital Med Lav Ergon. 2010 Jan-Mar;32(1):23-31. Italian.

11. Sannolo N, Lamberti M, Pedata P. [Human health effects of ultrafine particles]. G Ital Med Lav Ergon. 2010 OctDec;32(4 Suppl):348-51. Italian.

12. Garzillo EM, Lamberti M, Genovese G, Pedata P, Feola D, Sannolo N, et al. Blood lead, manganese, and aluminum levels in a regional Italian cohort of ALS patients: Does aluminum have an influence? J Occup Environ Med. 2014 Oct;56(10):1062-6, http://dx.doi.org/10.1097/ JOM.0000000000000266.

13. Mattioli S, Zanardi F, Baldasseroni A, Schaafsma F, Cooke RM, Mancini G, et al. Search strings for the study of putative occupational determinants of disease. Occup Environ Med. 2010 Jul;67(7):436-43, http://dx.doi.org/10.1136/ oem.2008.044727.

14. Das K, Nag C, Ghosh M. Familial, environmental and occupational risk factors in development of amyotrophic lateral sclerosis. N Am J Med Sci. 2012;4(8):350-5, http://dx.doi. org/10.4103/1947-2714.99517.

15. Armon C, Kurland LT, Daube JR, O'Brien PC. Epidemiologic correlates of sporadic amyotrophic lateral sclerosis. Neurology.1991 Jul;41(7):1077-84,http://dx.doi.org/10.1212/ WNL.41.7.1077. 
16. Chiò A, Meineri P, Tribolo A, Schiffer D. Risk factors in motor neuron disease: A case-control study. Neuroepidemiology. 1991;10(4):174-84, http://dx.doi.org/10.1159/000110267.

17. Fang F, Quinlan P, Ye W, Barber MK, Umbach DM, Sandler DP, et al. Workplace exposures and the risk of amyotrophic lateral sclerosis. Environ Health Perspect. 2009 Sep;117(9):1387-92, http://dx.doi.org/10.1289/ehp.0900580.

18. Sutedja NA, Veldink JH, Fischer K, Kromhout H, Wokke JH, Huisman MH, et al. Lifetime occupation, education, smoking, and risk of ALS. Neurology. 2007 Oct 9;69(15):1508-14, http://dx.doi.org/10.1212/01.wnl.0000277463.87361.8c.

19. Weisskopf MG, McCullough ML, Morozova N, Calle EE, Thun MJ, Ascherio A. Prospective study of occupation and amyotrophic lateral sclerosis mortality. Am J Epidemiol. 2005 Dec 15;162(12):1146-52, http://dx.doi.org/10.10 93/aje/kwi343.

20. McGuire V, Longstreth WT Jr., Nelson LM, Koepsell TD, Checkoway H, Morgan MS, et al. Occupational exposures and amyotrophic lateral sclerosis. A population-based casecontrol study. Am J Epidemiol. 1997 Jun 15;145(12):107688, http://dx.doi.org/10.1093/oxfordjournals.aje.a009070.

21. Strickland D, Smith SA, Dolliff G, Goldman L, Roelofs RI. Amyotrophic lateral sclerosis and occupational history. A pilot case-control study. Arch Neurol. 1996 Aug;53(8):730-3, http://dx.doi.org/10.1001/archneur.1996.00550080044011.

22. Sutedja NA, Fischer K, Veldink JH, van der Heijden GJ, Kromhout H, Heederik D, et al. What we truly know about occupation as a risk factor for ALS: A critical and systematic review. Amyotroph Lateral Scler. 2009 OctDec;10(5-6):295-301, http://dx.doi.org/10.3109/1748296080 2430799.

23. Vinceti M, Bottecchi I, Fan A, Finkelstein Y, Mandrioli J. Are environmental exposures to selenium, heavy metals, and pesticides risk factors for amyotrophic lateral sclerosis? Rev Environ Health. 2012;27(1):19-41, http://dx.doi.org/10. 1515/reveh-2012-0002.

24. Pamphlett R. Exposure to environmental toxins and the risk of sporadic motor neuron disease: An expanded Australian case-control study. Eur J Neurol. 2012 Oct;19(10):1343-8, http://dx.doi.org/10.1111/j.1468-1331.2012.03769.x.

25. Bettini M, Gargiulo-Monachelli GM, Rodríguez G, Rey RC, Peralta LM, Sica RE. Epidemiology of amyotrophic lateral sclerosis patients in a centre in Buenos Aires. Arq Neuropsiquiatr. 2011 Dec;69(6):867-70, http://dx.doi.org/10.1590/ S0004-282X2011000700003.

26. Gunnarsson LG, Lindberg G, Söderfeldt B, Axelson O. Amyotrophic lateral sclerosis in Sweden in relation to occupation. Acta Neurol Scand. 1991 Jun;83(6):394-8, http:// dx.doi.org/10.1111/j.1600-0404.1991.tb03970.x.

27. Bergomi M, Guidetti D, Vivoli R, Vinceti M. [The occupational risk factors for amyotrophic lateral sclerosis in an Italian community]. Ann Ig. 1998 Jul-Aug;10(4):249-53. Italian.

28. Pinkerton LE, Hein MJ, Meyers A, Kamel F. Assessment of ALS mortality in a cohort of formaldehyde-exposed garment workers. Amyotroph Lateral Scler Frontotemporal Degener. 2013 Sep;14(5-6):353-5, http://dx.doi.org/10.3109/ 21678421.2013.778284.

29. Pamphlett R, Rikard-Bell A. Different occupations associated with amyotrophic lateral sclerosis: Is diesel exhaust the link? PLoS One. 2013 Nov 11;8(11):e80993, http:// dx.doi.org/10.1371/journal.pone.0080993.

30. Furby A, Beauvais K, Kolev I, Rivain JG, Sébille V. Rural environment and risk factors of amyotrophic lateral sclerosis: A case-control study. J Neurol. 2010 May;257(5):792-8, http://dx.doi.org/10.1007/s00415-009-5419-5.

31. Hargreaves AJ. Neurodegenerations induced by organophosphorous compounds. Adv Exp Med Biol. 2012;724: 189-204, http://dx.doi.org/10.1007/978-1-4614-0653-2_15.

32. Govoni V, Granieri E, Fallica E, Casetta I. Amyotrophic lateral sclerosis, rural environment and agricultural work in the Local Health District of Ferrara, Italy, in the years 19641998. J Neurol. 2005 Nov;252(11):1322-7, http://dx.doi. org/10.1007/s00415-005-0859-z.

33. Bonvicini F, Marcello N, Mandrioli J, Pietrini V, Vinceti M. Exposure to pesticides and risk of amyotrophic lateral sclerosis: A population-based case-control study. Ann Ist 
Super Sanita. 2010;46(3):284-7, http://dx.doi.org/10.4415/ ANN_10_03_10.

34. Malek AM, Barchowsky A, Bowser R, Heiman-Patterson T, Lacomis D, Rana S, et al. Environmental and occupational risk factors for amyotrophic lateral sclerosis: A case-control study. Neurodegener Dis. 2014;14(1):31-8, http://dx.doi. org/10.1159/000355344.

35. Kamel F, Umbach DM, Bedlack RS, Richards M, Watson M, Alavanja MC, et al. Pesticide exposure and amyotrophic lateral sclerosis. Neurotoxicology. 2012 Jun;33(3):457-62, http://dx.doi.org/10.1016/j.neuro.2012.04.001.

36. Freedman M. Amyotrophic lateral sclerosis and occupational exposure to 2,4-dichlorophenoxyacetic acid. Occup Environ Med. 2001 Sep;58(9):609-10, http://dx.doi.org/10.1136/ oem.58.9.609a.

37. Doi H, Kikuchi H, Murai H, Kawano Y, Shigeto H, Ohyagi Y, et al. Motor neuron disorder simulating ALS induced by chronic inhalation of pyrethroid insecticides. Neurology. 2006 Nov 28;67(10):1894-5, http://dx.doi.org/10.1212/01. wnl.0000244489.65670.9f.

38. Kanavouras K, Tzatzarakis MN, Mastorodemos V, Plaitakis A, Tsatsakis AM. A case report of motor neuron disease in a patient showing significant level of DDTs, HCHs and organophosphate metabolites in hair as well as levels of hexane and toluene in blood. Toxicol Appl Pharmacol. 2011 Nov 1;256(3): 399-404, http://dx.doi.org/10.1016/j.taap.2011.07.022.

39. Malek AM, Barchowsky A, Bowser R, Youk A, Talbott EO. Pesticides exposure as a risk factor for amyotrophic lateral sclerosis: A meta-analysis of epidemiological studies. Environ Res. 2012;117:112-9, http://dx.doi.org/10.1016/j.envres.2012.06.007.

40. Pupillo E, Messina P, Logroscino G, Zoccolella S, Chiò A, Calvo A, et al. Trauma and amyotrophic lateral sclerosis: A case-control study from a population-based registry. Eur J Neurol. 2012;19(12):1509-17, http://dx.doi. org/10.1111/j.1468-1331.2012.03723.x.

41. Vanacore N, Cocco P, Fadda D, Dosemeci M. Job strain, hypoxia and risk of amyotrophic lateral sclerosis: Results from a death certificate study. Amyotroph Lateral Scler. 2010;11(5): 430-4, http://dx.doi.org/10.3109/17482961003605796.

42. McGuire V, Longstreth WT Jr., Nelson LM, Koepsell TD, Checkoway H, Morgan MS, et al. Occupational exposures and amyotrophic lateral sclerosis. A population-based casecontrol study. Am J Epidemiol. 1997;145(12):1076-88, http://dx.doi.org/10.1093/oxfordjournals.aje.a009070.

43. Johansen C. Exposure to electromagnetic fields and risk of central nervous system disease in utility workers. Epidemiology. 2000;11:539-43, http://dx.doi.org/10.1097/00001648200009000-00009.

44. Hakansson N, Gustavsson P, Johansen C, Floderus B. Neurodegenerative diseases in welders and other workers exposed to high levels of magnetic fields. Epidemiology. 2003;14:4206, http://dx.doi.org/10.1097/01.EDE.0000078446.76859.c9.

45. Savitz DA, Loomis DP, Tse CK. Electrical occupations and neurodegenerative disease: Analysis of U.S. mortality data. Arch Environ Health. 1998 Jan-Feb;53(1):71-4, http:// dx.doi.org/10.1080/00039899809605691.

46. Ruder AM, Hein MJ, Hopf NB, Waters MA. Mortality among 24,865 workers exposed to polychlorinated biphenyls (PCBs) in 3 electrical capacitor manufacturing plants: A ten-year update. Int J Hyg Environ Health. 2014 Mar;217 (2-3):176-87, http://dx.doi.org/10.1016/j.ijheh.2013.04.006.

47. Johansen C, Olsen JH. Mortality from amyotrophic lateral sclerosis, other chronic disorders, and electric shocks among utility workers. Am J Epidemiol. 1998 Aug 15;148(4):362-8, http://dx.doi.org/10.1093/oxfordjournals.aje.a009654.

48. Abhinav K, Al-Chalabi A, Hortobagyi T, Leigh PN. Electrical injury and amyotrophic lateral sclerosis: A systematic review of the literature. J Neurol Neurosurg Psychiatry. 2007;78:450-3, http://dx.doi.org/10.1136/jnnp.2006.104414.

49. Barth SK, Kang HK, Bullman TA, Wallin MT. Neurological mortality among U.S. veterans of the Persian Gulf War: 13-year follow-up. Am J Ind Med. 2009 Sep;52(9):663-70, http://dx.doi.org/10.1002/ajim.20718.

50. Ascherio A, Weisskopf MG, O'Reilly EJ, McCullough ML, Calle EE, Thun MJ. ALS and military service. Neurology. 
2005 Sep 27;65(6):972, http://dx.doi.org/10.1212/wnl. 65.6.972.

51. Mundt DJ, Dell LD, Luippold RS, Sulsky SI, Skillings A, Gross R, et al. Cause-specific mortality among Kelly Air Force Base civilian employees, 1981-2001. J Occup Environ Med. 2002 Nov;44(11):989-96, http://dx.doi. org/10.1097/00043764-200211000-00003.

52. Horner RD, Feussner JR, Kasarskis EJ. Prospective study of military service and mortality from ALS. Neurology. 2005 Jul 12;65(1):180-1, http://dx.doi.org/10.1212/WNL.65. 1.180-a.

53. Chiò A, Benzi G, Dossena M, Mutani R, Mora G. Severely increased risk of amyotrophic lateral sclerosis among Italian professional football players. Brain. 2005 Mar;128:472-6, http://dx.doi.org/10.1093/brain/awh373.

54. Al-Chalabi A, Leigh PN. Trouble on the pitch: Are professional football players at increased risk of developing amyotrophic lateral sclerosis? Brain. 2005 Mar;128:451-3, http:// dx.doi.org/10.1093/brain/awh426.

55. Lehman EJ, Hein MJ, Baron SL, Gersic CM. Neurodegenerative causes of death among retired National Football League players. Neurology. 2012 Nov 6;79(19):1970-4, http://dx.doi.org/10.1212/WNL.0b013e31826daf50.

56. Chiò A, Calvo A, Dossena M, Ghiglione P, Mutani R, Mora G. ALS in Italian professional soccer players: The risk is still present and could be soccer-specific. Amyotroph Lateral Scler. 2009 Aug;10(4):205-9, http://dx.doi. org/10.1080/17482960902721634.

57. Vanacore N, Binazzi A, Bottazzi M, Belli S. Amyotrophic lateral sclerosis in an Italian professional soccer player. Parkinsonism Relat Disord. 2006 Jun;12(5):327-9, http://dx.doi. org/10.1016/j.parkreldis.2005.11.007.

58. Belli S, Vanacore N. Proportionate mortality of Italian soccer players: Is amyotrophic lateral sclerosis an occupational disease? Eur J Epidemiol. 2005;20(3):237-42, http://dx.doi. org/10.1007/s10654-004-6879-7.

59. Pupillo E, Messina P, Giussani G, Logroscino G, Zoccolella S, Chiò A, et al. Physical activity and amyotrophic lateral sclerosis: A European population-based case-control study. Ann Neurol. 2014;75(5):708-16, http://dx.doi.org/10.1002/ ana.24150.

60. Veldink JH, Kalmijn S, Groeneveld GJ, Titulaer MJ, Wokke JH, van den Berg LH. Physical activity and the association with sporadic ALS. Neurology. 2005 Jan 25;64(2):2415, http://dx.doi.org/10.1212/01.WNL.0000149513.82332.5C.

61. Huisman MH, Seelen M, de Jong SW, Dorresteijn KR, van Doormaal PT, van der Kooi AJ, et al. Lifetime physical activity and the risk of amyotrophic lateral sclerosis. J Neurol Neurosurg Psychiatry. 2013 Sep;84(9):976-81, http:// dx.doi.org/10.1136/jnnp-2012-304724.

62. Davanipour Z, Sobel E, Vu H, Will AD. Electromagnetic field exposure and amyotrophic lateral sclerosis. Neuroepidemiology. 1991;10(5-6):308, http://dx.doi.org/10.1159/000110288.

63. Ahlbom IC, Cardis E, Green A, Linet M, Savitz D, Swerdlow A, et al. Review of the epidemiologic literature on EMF and health. Environ Health Perspect. 2001 Dec;109 Suppl 6:911-33, http://dx.doi.org/10.2307/3454653.

64. Li CY, Sung FC. Association between occupational exposure to power frequency electromagnetic fields and amyotrophic lateral sclerosis: A review. Am J Ind Med. 2003 Feb;43(2):212-20, http://dx.doi.org/10.1002/ajim.10148.

65. Parlett LE, Bowman JD, van Wijngaarden E. Evaluation of occupational exposure to magnetic fields and motor neuron disease mortality in a population-based cohort. J Occup Environ Med. 2011 Dec;53(12):1447-51, http://dx.doi. org/10.1097/JOM.0b013e318237a1d0.

66. Noonan CW, Reif JS, Yost M, Touchstone J. Occupational exposure to magnetic fields in case-referent studies of neurodegenerative diseases. Scand J Work Environ Health. 2002 Feb;28(1):42-8, http://dx.doi.org/10.5271/sjweh.645.

67. Röösli M, Lörtscher M, Egger M, Pfluger D, Schreier N, Lörtscher E, et al. Mortality from neurodegenerative disease and exposure to extremely low-frequency magnetic fields: 31 years of observations on Swiss railway employees. Neuroepidemiology. 2007;28(4):197-206, http://dx.doi. org $/ 10.1159 / 000108111$. 
68. Poulletier de Gannes F, Ruffié G, Taxile M, Ladevèze E, Hurtier A, Haro E, et al. Amyotrophic lateral sclerosis (ALS) and extremely-low frequency (ELF) magnetic fields: A study in the SOD-1 transgenic mouse model. Amyotroph Lateral Scler. 2009 Oct-Dec;10(5-6):370-3, http:// dx.doi.org/10.3109/17482960802320396.

69. Zhou H, Chen G, Chen C, Yu Y, Xu Z. Association between extremely low-frequency electromagnetic fields occupations andamyotrophic lateral sclerosis: A meta-analysis. PLoS One. 2012;7(11):e48354, http://dx.doi.org/10.1371/ journal.pone.0048354.

70. Kheifets L, Bowman JD, Checkoway H, Feychting M, Harrington JM, Kavet R, et al. Future needs of occupational epidemiology of extremely low frequency electric and magnetic fields: Review and recommendations. Occup Environ Med. 2009 Feb;66(2):72-80, http://dx.doi.org/10.1136/ oem.2007.037994.

71. D'Amico E, Factor-Litvak P, Santella RM, Mitsumoto H. Clinical perspective on oxidative stress in sporadic amyotrophic lateral sclerosis. Free Radic Biol Med. 2013 Dec;65:509-27, http://dx.doi.org/10.1016/j.freeradbiomed.2013.06.029.

72. Bastos AF, Orsini M, Machado D, Mello MP, Nader S, Silva JG, et al. Amyotrophic lateral sclerosis: One or multiple causes? Neurol Int. 2011 Jun;3(1):e4, http://dx.doi. org/10.4081/ni.2011.e4.

73. Modgil S, Lahiri DK, Sharma VL, Anand A. Role of early life exposure and environment on neurodegeneration: Implications on brain disorders. Transl Neurodegener. 2014 Apr 29;3:9, http://dx.doi.org/10.1186/2047-9158-3-9.

74. Gresham LS, Molgaard CA, Golbeck AL, Smith R. Lead exposure and ALS. Neurology. 1992 Nov;42(11):2228-9, http://dx.doi.org/10.1212/WNL.42.11.2228-a.

75. Kamel F, Umbach DM, Munsat TL, Shefner JM, Hu H, Sandler DP. Lead exposure and amyotrophic lateral sclerosis. Epidemiology. 2002 May;13(3):311-9, http://dx.doi. org/10.1097/00001648-200205000-00012.

76. Oh SS, Kim EA, Lee SW, Kim MK, Kang SK. A case of amyotrophic lateral sclerosis in electronic parts manufacturing worker exposed to lead. Neurotoxicology 2007;28:324-7, http://dx.doi.org/10.1016/j.neuro.2006.12.004.

77. Hozumi I, Hasegawa T, Honda A, Ozawa K, Hayashi Y, Hashimoto K, et al. Patterns of levels of biological metals in CSF differ among neurodegenerative diseases. J Neurol Sci. 2011 Apr 15;303(1-2):95-9, http://dx.doi.org/10.1016/ j.jns.2011.01.003.

78. Callaghan B, Feldman D, Gruis K, Feldman E. The association of exposure to lead, mercury, and selenium and the development of amyotrophic lateral sclerosis and the epigenetic implications. Neurodegener Dis. 2011;8(1-2):1-8, http:// dx.doi.org/10.1159/000315405.

79. Schwarz S, Husstedt I, Bertram HP, Kuchelmeister K. Amyotrophic lateral sclerosis after accidental injection of mercury. J Neurol Neurosurg Psychiatry. 1996;60:698, http:// dx.doi.org/10.1136/jnnp.60.6.698.

80. Roos PM, Dencker L. Mercury in the spinal cord after inhalation of mercury. Basic Clin Pharmacol Toxicol. 2012 Aug;111(2):126-32, http://dx.doi.org/10.1111/j.1742-7843. 2012.00872.x.

81. Pamphlett R, Kum Jew S. Uptake of inorganic mercury by human locus ceruleus and corticomotor neurons: Implications for amyotrophic lateral sclerosis. Acta Neuropathol Commun. 2013 May 9;1(1):13, http://dx.doi.org/10.1186/ 2051-5960-1-13.

82. Zahir F, Rizwi SJ, Haq SK, Khan RH. Low dose mercury toxicity and human health. Environ Toxicol Pharmacol. 2005 Sep;20(2):351-60, http://dx.doi.org/10.1016/ j.etap.2005.03.007.

83. Praline J, Guennoc AM, Limousin N, Hallak H, de Toffol B, Corcia P. ALS and mercury intoxication: A relationship? Clin Neurol Neurosurg. 2007 Dec;109(10):880-3, http:// dx.doi.org/10.1016/j.clineuro.2007.07.008.

84. Rooney J. Further thoughts on mercury, epigenetics, genetics and amyotrophic lateral sclerosis. Neurodegener Dis. 2011;8(6):523-4, http://dx.doi.org/10.1159/000324518.

85. Roos PM, Vesterberg O, Syversen T, Flaten TP, Nordberg M. Metal concentrations in cerebrospinal fluid and blood 
plasma from patients with amyotrophic lateral sclerosis. Biol Trace Elem Res. 2013 Feb;151(2):159-70, http://dx.doi. org/10.1007/s12011-012-9547-x.

86. Bar-Sela S, Reingold S, Richter ED. Amyotrophic lateral sclerosis in a battery-factory worker exposed to cadmium. Int J Occup Environ Health. 2001 Apr-Jun;7(2):109-12.

87. Bar-Sela S, Levy M, Westin JB, Laster R, Richter ED. Medical findings in nickel-cadmium battery workers. Isr J Med Sci. 1992 Aug-Sep;28(8-9):578-83.

88. Tokuda E, Ono S, Ishige K, Naganuma A, Ito Y, Suzuki T. Metallothionein proteins expression, copper and zinc concentrations, and lipid peroxidation level in a rodent model for amyotrophic lateral sclerosis. Toxicology. 2007;229:3341, http://dx.doi.org/10.1016/j.tox.2006.09.011.

89. Valentine JS, Hart PJ. Misfolded CuZnSOD and amyotrophic lateral sclerosis. Proc Natl Acad Sci U S A. 2003;100: 3617-22, http://dx.doi.org/10.1073/pnas.0730423100.
90. Sińczuk-Walczak H. [Nervous system disorders induced by occupational exposure to aluminium compounds: A literature review]. Med Pr. 2001;52(6):479-81. Polish.

91. Qureshi IA, Mehler MF. Advances in epigenetics and epigenomics for neurodegenerative diseases. Curr Neurol Neurosci Rep. 2011;11:464-73, http://dx.doi.org/10.1007/s11910011-0210-2.

92. Trojsi F, Monsurrò MR, Tedeschi G. Exposure to environmental toxicants and pathogenesis of amyotrophic lateral sclerosis: State of the art and research perspective. Int J Mol Sci. 2013;14:15286-311, http://dx.doi.org/10.3390/ ijms140815286.

93. Sreedharan J, Brown RH Jr. Amyotrophic lateral sclerosis: Problems and prospects. Ann Neurol. 2013 Sep;74(3):30916, http://dx.doi.org/10.1002/ana.24012.

This work is available in Open Access model and licensed under a Creative Commons Attribution-NonCommercial 3.0 Poland License - http://creativecommons.org/ licenses/by-nc/3.0/pl/deed.en. 